\section{Using different anaesthesia techniques during arthrocentesis: case series}

\section{Artrosentez işleminde iki farklı anestezi tekniğinin kullanımı: olgu serisi}

\author{
Assoc. Prof. Yusuf Emes \\ Istanbul University, Faculty of Dentistry, Dept. of Oral \\ and Maxillofacial Surgery, Istanbul.
}

\section{Dr. Itır Şebnem Bilici}

Private Practice

\section{Prof. Buket Aybar}

Istanbul University, Faculty of Dentistry, Dept. of Oral and Maxillofacial Surgery, Istanbul

\section{Dt. Anıl Cesur}

Istanbul University, Faculty of Dentistry, Dept. of Oral and Maxillofacial Surgery, Istanbul

\section{Dt. Uğur Aga}

Istanbul University, Faculty of Dentistry, Dept. of Oral and Maxillofacial Surgery, Istanbul

\section{Assoc. Prof. Melike Ordulu Sübay}

Istanbul University, Faculty of Dentistry, Dept. of Oral and Maxillofacial Surgery, Istanbul

Prof. Halim İşsever

Istanbul University, Istanbul Faculty of Medicine,

Dept. of Public Health, Istanbul

\section{Prof. Serhat Yalçın}

Private practice

Received: 4 March 2017

Accepted: 7 April 2017

DOI: 10.5505/yeditepe.2017.46220

\section{Corresponding author:}

Prof. Buket Aybar

Istanbul University Faculty of Dentistry,

Department of Oral and Maxillofacial Surgery

34093 Çapa/istanbul.

Phone: +90 (212) 4142020 - 32168

E-mail: buketaybar@hotmail.com

\section{SUMMARY}

Internal derangement of the temporomandibular joint (TMJ) can be defined as a disorder of the intracapsular components of the joint, which is originated by displacement of the disc from its normal functional relationship with the condyle of the mandible and the temporal bones articular fossa. The most common symptoms of temporomandibular joint internal derangement vary from simple joint sounds to locking and pain. The aim of this case series is to evaluate the effects of GowGates anaesthesia technique, which blocks the auriculotemporal nerve, in combination with an intracapsular local anaesthetic injection, on patient comfort during artrocenthesis. 24 patients had arthrocentesis due to temporomandibular disorder complaints. We suggest that further studies might give more information about the patient comfort during artrocenthesis. Internal derangement of the temporomandibular joint (TMJ) the most common form of temporomandibular disorders. It affects patient's daily life with pain, dysfunction, joint sounds, and even aural symptoms.

Key words: Temporomandibular joint (TMJ), artrocenthesis gow-gates, visual analogue scale (VAS).

\section{ÖZET}

Temporomandibular eklemin (TME); internal düzensizlikleri; diskin mandibular kondil ve temporal kemikteki artikuler fossa ile olan normal konumundan uzaklaşması ile meydana gelir. Internal düzensizlik basit eklem seslerinden kilitlenmeye ve ağrıya kadar giden semptomlar gösterir. Bu yazının amacl; Gow Gates anestezi tekniği ile birlikte intrakapsüler lokal anestezi enjeksiyonun artrosentez esnasında hasta konforu üzerine etkisini incelemektir. Artrosentez işlemi konservatif yöntemlere yanıt vermeyen 24 hastada uygulanmıştır. Sonuç olarak; artrosentez esnasında hasta konforunu arttırmak için kontrollü randomize klinik çalışmalara intiyaç olduğunu düşünmekteyiz. İnternal düzensizlikler; TME'nin en yaygın rahatsızlıklarındandır. Hastanın günlük hayatını, ağrı, disfonksiyon, eklem sesi ve hatta aural semptomları değiştirerek etkiler.

Anahtar kelimeler: Temporomandibuler eklem, artrosentez, Gow-GAtes anestezi, görsel analog skala.

\section{INTRODUCTION}

The temporomandibular joint (TMJ) is between the squamous portion of the temporal bone (glenoid fossa) and the condyle of the mandible. The joint has its articular surfaces covered with a synovial membrane and also contains an articular disc, and ligaments. Temporomandibular joint is innervated by the auriculotemporal nerve which is originated from the mandibular division of the trigeminal nerve. ${ }^{1}$

Temporomandibular joint disorders can sometimes be misdiagnosed, and treatment can sometimes be not carried out properly in medical and dental practice. Difficulties in understanding the temporomandibular disorders stem from 
the physicians' traditional habit of assessing disorders from a one etiology-one treatment perspective. Internal derangement of the temporomandibular joint (TMJ) the most common form of temporomandibular disorders ${ }^{2}$ which affects the patient's daily life due to pain, los of function, joint sounds, and even aura like symptoms. ${ }^{3,4}$ Internal derangement of the temporomandibular joint can be defined as a incoordination of the internal aspects of the TMJ which is originated by displacement of the disk from its normal functional relationship with the bony components of the joint, namely the mandibular condyle and the articular surface of the temporal bone. ${ }^{5}$

The presence of pain in the TMJ is believed to be related to the concentration of inflammatory mediators within the joint ${ }^{6,7}$ Initially, these symptoms may be managed by conservative ttratment modalities, namely consumption of soft diet, taking analgesics and non-steroidal anti inflammatory drugs, antidepressants. Patient education is also an initial treatment method of TMD. ${ }^{8}$

The other conservative treatment options for dysfunction of the temporomandibular joint (TMJ), are physiotherapy and fabrication of stabilization splints, for reducing the mechanical loads on the joint in order to relieve pain. If conservative methods fail, arthrocentesis may be indicated to recover mandibular functions. ${ }^{9}$

Arthrocentesis of the TMJ was first described by Nitzan et al. ${ }^{2}$ in 1991, and is done by irrigating the upper joint space for manipulating the joint, which releases the adhesions to improve function.

The simple lavage of the upper joint compartment under local anaesthesia is performed in order to maintain an easy motion of the disc and to reestablish a normal range of mouth opening in patients with closed lock. Today, TMJ arthrocentesis is used not only in the treatment of acute closed lock but also in various other intraarticular temporomandibular disorders. ${ }^{10}$ The therapeutic effect of arthrocentesis can be explained by the removal of the any inflammatory mediators from the joint, reducing pain and loosening the adherent disc by hydraulic pressure. ${ }^{11,12}$

Arthrocentesis treatment procedure can be done under either general or local anaesthesia. Although joint cannot be manipulated aggressively under local anaesthesia, no significant differences have been found between the treatments done under local or general anaesthesia ${ }^{13}$ however, clinical experience shows that under local anaesthesia, patients might feel pain during arthrocentesis. The aim of this paper, is to report the effect of Gow-Gates mandibular block technique which anaesthetises the auriculotemporal nerve, ${ }^{14}$ on patient comfort during arthrocentesis.

\section{CASES}

24 female patients aged 23 to 64 years, who were all diagnosed with internal derangement of the temporomandibular joint (TMJ) and who did not reply to conservative treatment modalities were referred to our clinic for arthrocentesis. Visual analogue scale (VAS) was used for intra-operative pain evaluation and this score was used as an indicator of patient comfort during arthrocentesis. The patients were asked to state the highest amount of pain they have felt during the operation. Before the procedure pain complaints of the patients were recorded Eleven patients received Gow-Gates mandibular block in order to block the auriculotemporal nerve prior to intraarticular - pericapsular local anaesthetic injection. Thirteen patients had arthrocentesis performed only with intraarticular and pericapsular injection. All of the operations were performed by the same surgeon and the same anaesthetic solution was used in all patients. Arthrocentesis was done as described by Nitzan et al. ${ }^{2}$ and $50 \mathrm{cc}$ of linger's lactate solution was used in all of the patients. At the end of the lavage, sodium hyaluronate was intraarticularly injected (ORTHOVISC ${ }^{\circledR}$ Anika Therapeutics Inc. Woburn, MA USA). Only seven patients reported no pain during the operation. 6 patients in both groups reported pain (VAS:8) (Table 1)

Table 1: Patients and their intraoperative VAS scores

\begin{tabular}{|c|c|c|}
\hline \multicolumn{3}{|c|}{ Gow-Gates and intraarticular injection } \\
\hline Patient No: & Age & Intra-operative VAS \\
\hline 1 & 35 & 0 \\
\hline 2 & 23 & 1 \\
\hline 3 & 42 & 1 \\
\hline 4 & 29 & 1 \\
\hline 5 & 27 & 7 \\
\hline 6 & 55 & 2 \\
\hline 7 & 27 & 0 \\
\hline 8 & 26 & 8 \\
\hline 9 & 28 & 8 \\
\hline 10 & 24 & 3 \\
\hline 11 & 31 & 0 \\
\hline \multicolumn{3}{|c|}{ Intraarticular injection } \\
\hline Patient No: & Age & Intra-operative VAS \\
\hline 12 & 26 & 8 \\
\hline 13 & 23 & 0 \\
\hline 14 & 27 & 1 \\
\hline 15 & 40 & 8 \\
\hline 16 & 22 & 6 \\
\hline 17 & 42 & 1 \\
\hline 18 & 27 & 8 \\
\hline 19 & 35 & 1 \\
\hline 20 & 25 & 0 \\
\hline 21 & 40 & 0 \\
\hline 22 & 58 & 8 \\
\hline 23 & 64 & 2 \\
\hline 24 & NA & 0 \\
\hline
\end{tabular}




\section{DISCUSSION}

Clinical experience shows that it can be difficult to access the superior joint space during arthrocentesis therefore anaesthesia is the most important part to find the right place to insert the needles without pain.

Various authors have used general and local anaesthesia for artrocenthesis. Ziegler et.al. ${ }^{15}$ reported that using morphine with local anaesthesia (bupivacaine) led to decrease in pain during and after the operation in their patients. Tuz et.al. ${ }^{3}$ reported about the differences between the local and general anaesthesia techniques during arthrocentesis concluding that general anaesthesia is more comfortable for patients during operation.

Contradictionally, Ramasamy et.al. ${ }^{16}$ evaluated the outcomes of general and local anaesthesia operations and they suggested that the arthrocentesis under local anaesthesia is preferable due to the risks of general anaesthesia.

In their study, Park et. al. ${ }^{17}$ observed that the local anaesthesia is necessary for arthrocentesis procedure their results showing that deep needle procedures without anaesthesia are painful to the majority of patients.

We have aimed to show the differences between the two local anaesthesia techniques and their contribution to patient comfort during artrocenthesis. When we evaluate the 24 cases we could not show any advantage of using the Gow-Gates mandibular block for the anaesthesia of the auriculotemporal nerve during arthrocentesis. The mean value of VAS scores in both groups show that patients might feel pain to some extent during the operation even if under local anaesthesia.

Gow-Gates is a simple and safe anaesthesia technique which blocks the auricuotemporal nerve along with inferior alveolar and buccal nerves.

\section{CONCLUSION}

The main drawback of our technique is, Gow-Gates anaesthesia requires a high range of mouth opening, which is not present in most TMD patients. Further studies utilising extraoral anaesthesia techniques for auriculotemporal nerve may give more information on the effects of auriculotemporal nerve block on patient comfort during artrocenthesis.

\section{REFERENCES}

1. Norton Neil S. Netter's head and neck anatomy for dentistry. 2nd ed. 236-242.

2. Nitzan DW, Dolwick MF, Martinez GA. Temporomandibular joint arthrocentesis. A simplified treatment for severe limited mouth opening. J Oral Maxillofac Surg 1991; 49: 1163-1167.

3. Tuz HH, Onder EM, Kisnisci RS. Prevalence of otologic complaintsin patients with temporomandibular disorder.
Am J Orthod Dentofacial Orthop 2003; 123: 620-623.

4. Hancı M, Karamese M, Tosun Z, Aktan TM, Duman S, Savaci N. Intra-articular platelet-rich plasmainjection for the treatment of temporomandibular disorders and a com-parison with arthrocentesis. J Craniomaxillofac Surg 2015; 43: 162-166.

5. Lee S, Yoon HJ, MRI Findings of patients with temporomandibular joint internal derangement: before and after performance of arthrocentesis and stabilization splint. J Oral Maxillofac Surg 2009; 67: 314-317.

6. Milam SB, Schmitz JP: Molecular biology of temporomandibular joint disorders: Proposed mechanisms of disease. J Oral Maxillofac Surg 1995; 53:1448-1454.

7. Bouloux GF. Temporomandibular joint pain and synovial fluid analysis: A review of the literature. J Oral Maxillofac Surg 2009; 67: 2497-2504.

8.Vasconcelos BC, Bessa-Nogueira RV, Rocha NS. Temporomandibular joint arthrocententesis: evaluation of results and review of the literature. Rev Bras Otorrinolaringol 2006; 72: 634-638.

9. Monje-Gil F, Nitzan D, González-Garcia R. Temporomandibular jointarthrocentesis. Review of the literature. Med Oral Patol Oral Cir Buccal 2012; 17: 575-581.

10. Alpaslan GH, Alpaslan C. Efficacy of temporomandibular joint arthrocentesis with and without injection of sodium hyaluronate in treatment of internal derangements. J Oral Maxillofac Surg 2001; 59: 613-618.

11. Kuruvilla VE, Prasad K. Arthrocentesis in TMJ internal derangement: aprospective study. J Maxillofac Oral Surg 2012; 11: 53-56.

12. Tozoglu S, Bayramoglu Z, Ozkan O. Outcome of otologic symp-toms after temporomandibular joint arthrocentesis. J Craniofac Surg 2015; 26: 344-376.

13. Tuz HH, Baslarli O, Adiloglu S, Gokturk T, Meral SE. Comparison of local and general anaesthesia forarthrocentesis of the temporomandibular joint, British Journal of Oral and Maxillofacial Surgery 2016; 54: 946-949.

14. Meechan JG. Local Anesthesis in Oral and Maxillofacial Surgery. Andersson L, Kahnberg K, Pogrel MA eds. Wiley-Blackwell West Sussex UK. 2010.

15. Ziegler CM, Wiechnik J, Mühling J. Analgesic Effects of Intra-Articular Morphine in Patients With Temporomandibular Joint Disorders: A Prospective, Double-Blind, Placebo-Controlled Clinical Trial. J Oral Maxillofac Surg 2010; 68: 622-627.

16. Ramasamy A, Madhan B. Re: Comparison of local and general anaesthesia for arthrocentesis of the temporomandibular joint. British Journal of Oral and Maxillofacial Surgery. 2017 Feb 24.

17. Park KS, Peisajovich A, Michael AA, Sibbitt Jr WL, Bankhurst AD. Should local anesthesia be used for arthrocentesis and joint injections? Rheumatology international. 2009; 29: 721-723. 